\title{
The Fryderyk Chopin heritage legacy in the perspective of the local community and tourists
}

\section{Anna Ostrowska-Tryzno, Anna Pawlikowska-Piechotka}

\begin{abstract}
Although cultural tourism has been known since the very beginning of the European civilisation (the Ancient Greeks and Romans peregrines'), nowadays cultural events are a great attraction not only for a local community, but they are also a strong motivation for tourists to travel. It seems that one of the special research value is to consider how deeply cultural events, connected with 'high art' (museums, classical music, art events of superior quality), motivate a local community and tourists. Therefore, the main aim of our survey was to recognize the role and contribution of top cultural events (on the example of 'the Chopin Year 2010') in marketing a city's image and to evaluate its significance as a tourist attraction and its meaning to the local community. To examine the cultural tourism from visitors and the local community perspective and to obtain primary data, we undertook the explanatory and evaluative research. We also used (as secondary data) an academic literature review results, statistic information and materials obtained from the Chopin Museum in Warsaw, the Fryderyk Chopin Association and the Fryderyk Chopin Institute. This paper describes the main outcomes of the survey conducted in 20112015. In the past, cultural activities were rarely regarded as part of the tourism industry in Warsaw. The International Fryderyk Chopin Festivals and the International Fryderyk Chopin Piano Competitions were considered as different. From the beginning, they were aimed to be widely recognised international events, rather than attractions organised to meet the needs of the residents and domestic tourists. However, 'the Chopin Year 2010' celebrations remained highly exceptional as many different events took place, including 'street music.' They were aimed broader than to satisfy only a rather narrow niche of professional musicians. In 2010 both the International Fryderyk Chopin Festival and the 16th International Fryderyk Chopin Piano Competition were events not only shaped for special groups of music lovers, but also for the local community who was able to actively participate in these two big festivals.
\end{abstract}

Key words: The Fryderyk Chopin heritage, cultural events, local community and tourists, Warsaw

\section{Introduction}

Although cultural tourism has been known since the very beginning of the European civilisation now it grows rapidly. It has nearly half of the tourism segment industry. The Ancient Greeks and Romans peregrines' to historic sites, offering artistic and cultural events and shows, were undertaken with the aim of entertainment and acquiring knowledge. Nowadays cultural events are a great attraction not only for a local community but they are also a strong motivation for tourists to travel to the European historic cities. The 'culturally motivated' visitors want to learn more about history, tradition, culture, take part in interesting festivals, concerts, theatre performances and historic battle re-enactments with the same aim as their 
ancestors had two thousand years ago: entertainment and experiencing pleasure combined with meeting intellectual and individual growth needs. But rarely a single attraction is enough. The researchers with different academic backgrounds strongly underline that cultural tourism is based on the whole mosaic of places, traditions, art forms, celebrations and experiences - on the rich variety of tangible and intangible cultural heritage [Archer, Cooper, Ruhanen 2004; Dallen, Boyd 2003; Kowalczyk 2009; Loykie, Edmunds 2007; Rohrscheidt 2008; Sigala, David 2006; Smith 2003].

According to the definition of cultural tourism, adapted by the UN World Tourism Organization (UNWTO) in 2017, these type of travels are described as: 'A type of tourism activity in which the visitor's essential motivation is to learn, discover, experience and consume the tangible and intangible cultural attractions and products related to a set of distinctive material, intellectual, spiritual and emotional features of a society that encompasses arts and architecture, historical and cultural heritage, literature, music, creative industries and the living cultures with their styles, value systems, beliefs and traditions' [UNWTO 2017].

Following this definition, cultural tourism is strongly connected with historic cities and their cultural offer (museums, theatres, festivals, cultural attractions and events). Therefore, an educational value might be considered, if cultural tourism is connected with 'high art' (museums, art galleries, classical music concerts and festivals). For some travellers, it is a lifestyle to participate in music festivals and events. Thus, the researches distinguish 'music tourism' as a special form of tourism [Smith 2003; UNWTO 2002; UNWTO 2017].

As a matter of fact, 'music tourism' is not a new interest or a recently developed notion. In the late 19th and the whole 20th century a great number of tourists visited Duszniki Zdrój in Lower Silesia - because of Fryderyk Chopin; Bergen - because of Edward Grieg; Leipzig - because of Richard Wagner and Johann Sebastian Bach; Bonn - for Ludwig van Beethoven; Salzburg and Vienna - for Wolfgang Amadeus Mozart. Today numbers of tourists in London visit not only The Tower of London but also Abbey Road to take an iconic selfie at the zebra crossing (inspired by the famous cover of the Beatles' long play); in Liverpool, they try to find traces of The Beatles while the others visit Memphis (Tennessee, US) to give tribute to the legend of Elvis Presley.

Warsaw is also often associated with many famous musicians: Fryderyk Chopin, Witold Lutosławski, Ignacy Paderewski and more recently with Krzysztof Komeda-Trzciński, Czesław Niemen and Krzysztof Penderecki. On the base of connections with outstanding composers of classical and contemporary music, every year the city hosts a wide range of concerts and festivals. Among them, the Witold Lutosławski Music Festival, Jazz Jamboree Festival, Warsaw Autumn Music Festival, Summer Music Gardens Festival and Ludwig van Beethoven Easter Festival - all these are music events with international recognition. However, in the last decade, the exceptional events attracting numerous visitors were mainly connected with 'the Chopin Year 2010' in Warsaw. To celebrate the 200th Anniversary of Chopin's birthday there were numerous concerts and cultural events organized. They took place in Warsaw from 22nd of February (Chopin's Birthday) to the end of 2010. 'A Varsovian 
by birth, a Pole at heart, a citizen of the world by virtue of his talent'. This is what Cyprian Kamil Norwid, a Polish romantic visionary poet and devoted admirer of the composer, said about Chopin. Although Fryderyk Chopin had special connections with Warsaw, Mazovia, Poland and Europe, his works have been published and played across the whole world and his popularity remains strong on all continents [NFCHI 2010, 2011].

\section{Research Materials and Methods}

The year 2010, in which the 200th anniversary of Fryderyk Chopin birth took place, was dedicated by Warsaw City Council to the memory of our famous composer. Undoubtedly, many events organised in Warsaw (and in other Polish cities) were a significant tourist attraction and had a special role in the regional promotion and cultural education. Therefore, it seems that it is of special research value to consider how deeply cultural tourism is connected with 'high art' (as 'the Chopin Year 2010' events in Warsaw). Consequently, the main aim of our survey, conducted by the Faculty of Tourism and Recreation at the Joseph Pilsudski University of Physical Education in Warsaw (2011-2015), based on the grant Ds-144 of Ministry of Science and Higher Education, was to:

- Recognize the role and contribution of urban culture in marketing a city's image demonstrated through 'the Chopin Year 2010' and its outcomes in Warsaw,

- Understand the role of 'high art' (Chopin myth) in the cultural policy of the Warsaw City Council and management of the major cultural events in Warsaw,

- Analyse the direct and indirect outcomes resulting from the 200th Anniversary of Chopin's birthday celebrations (in the context of cultural tourism development and in the local community perspective).

When seeking answers to the following questions, the application of different research methods and tools was required: qualitative approach mixed with quantitative approach and literature studies to prelude field studies (case studies) [Finn, Elliott-White 2000; Law 2002; Phillimore, Goodson 2004; Selby 2004; Sigala 2006]. To examine urban tourism from the local community and tourists' perspective and to obtain primary data, we undertook the explanatory research. It was based on the field survey: participants' observation, structured interviews in the form of a semi-scheduled questionnaire - providing a basis to explain some phenomena (these were undertaken in April and May 2012-2014). Our evaluative research helped us to recognize the policy of the Warsaw City Council on cultural events and sustainable tourism. We also used (as secondary data) academic literature review, statistic information and materials obtained from the Fryderyk Chopin Museum in Warsaw and the Fryderyk Chopin Institute. Research for this article results also from an extensive academic literature and popular literature review, including a systematic review of the bulletins issued in 2010 in Warsaw to commemorate 'the Chopin Year 2010' (like 'Chopin Express' published during the 16th International Chopin Piano Competition or 'Chopin 1810-1848' published 
by the Fryderyk Chopin Institute in Warsaw) [NFCHI 2010, 2011]. Field studies in Warsaw were ongoing between 2012 and 2014 and this paper describes the main outcomes resulting from the survey. ${ }^{1}$

\section{Case study of 'the Chopin Year 2010' legacy in Warsaw}

The celebrating of 'the Chopin Year 2010' was a time of many important cultural events in Warsaw. For example, The International Fryderyk Chopin Festival; the 16th International Chopin Piano Competition; series of Chopin Concerts under the Willow Tree in the Royal Łazienki Park; re-opening the Fryderyk Chopin Museum in Warsaw; opening the 'Chopin Tourist Route' and 'Chopin Multimedia Benches.' These cultural projects were organised mainly by Warsaw City Council together with the Fryderyk Chopin Institute (NFCHI). Moreover, in 2010 the Fryderyk Chopin Institute together with the City Council organized a series of special concerts celebrating Fryderyk Chopin's 200th birthday anniversary [NFCHI 2010, 2011]. These outstanding events that took place in many venues in spring, summer and autumn of 2010. The most important of them were:

- Music Presentations in Żelazowa Wola (May-September 2010),

- Sunday Chopin concerts in Żelazowa Wola (May-September 2010),

- Sunday Chopin Concerts under the Willow Tree, by the Chopin Monument in Łazienki Park (May-September 2010),

- The International Chopin Festival 'Chopin and His Europe' (August-September 2010).

It is to be underlined that the City Council and the Fryderyk Chopin Institute were also involved in the organization of 'The 16th International Chopin Piano Competition' in 2010.

Field surveys undertaken in Warsaw (in the form of participant observations and face to face, in situ structured interviews, PAPI method was used) were conducted with the participation of students from the Faculty of Tourism and Recreation AWF University in Warsaw. These field studies were conducted during spring semesters of the following academic years: 2012/2013, 2013/2014 and 2014/2015 (as a part of History of Art and Architecture coursework). On the whole, we have received 120 interviews from adults, who were informed about the aim of the research and agreed to take part in the scheduled interviews (local community members and tourists). The interviews were focused on 'the Chopin Year 2010' legacy (considered 1, 2 and 3 years after these events) and 'Chopin Tourist Route' in Warsaw. We decided for a more qualitative than quantitative approach, as it is considered a more appropriate research method in tourism offering trustworthiness and holistic account [Phillimore,

\footnotetext{
${ }^{1}$ Field surveys (in the form of face to face, in situ structured interviews, PAPI method was used) were conducted with the participation of students from the Faculty of Tourism and Recreation AWF University in Warsaw and the WSHGiT University in Warsaw, under supervision of prof. Anna PawlikowskaPiechotka (spring semesters of 2011-2015). On the whole, we have received 120 interviews from adults, who were informed about the research and had agreed to take part in the scheduled interviews (local community members and tourists).
} 
Goodson 2004]. It is to be underlined, that we were aware that our research scope would be limited and quantitative data might not be representative (due to the limited number of our responders). During field studies in Warsaw, we used mixed techniques (participant observations, structured interviews, photography). Our framework and works calendar in 2011-2017 were as follows:

2011 - research design, methods are chosen (approach, techniques, tools), research agenda and calendar (detailed scenario),

2012-2014 - case studies in Warsaw, field works, interviews and participatory observations conducted in the selected sites,

2015-2017 - analysis of findings, data interpretations, first findings and conclusions.

However hard we tried to be objective and make our research scenario rigorous, it is to be noted that our research study was limited in scale to the local level (Warsaw, tourists and local community members) and time. Therefore, our findings offer a snapshot of a particular time and the Fryderyk Chopin heritage and legacy seen through the limited group perspective (120 respondents of different age and gender). Researchers' voice in the presented conclusions is one among many.

\section{‘Chopin Tourist Route' - tourists and the local community perspective}

In 2010, to celebrate the 200th Anniversary of Fryderyk Chopin's birth, Warsaw City Council developed an interesting project: 'Chopin Tourist Route' with 'Chopin Multimedia Benches' [www.e-warsaw.pl, www.um.warszawa.pl/chopin2010] (Figs. 1-16). This project was very carefully designed as locations of the 'music benches' were based on the top tourist attractions - the Old Town and the Royal Route. The music benches were located next to the places associated with Fryderyk Chopin, which are also historic objects and monuments (palaces, churches). The aim of the route was to promote the historic spots in Warsaw connected with the memory of Fryderyk Chopin. By following the 'Chopin Tourist Route', both Warsaw residents and tourists could discover the picturesque areas connected with the great composer. The 'Chopin Multimedia Benches' allow easily enjoying Chopin's music in the selected places. All that is needed is to press a button and the bench will play a fragment of Chopin's composition, providing additional information (in Polish or English). One can also use the supplement audio guide issued by Warsaw City Council. The 'Chopin Tourist Route' experience is also available on the Internet (on a specially designed website: www. um.warszawa.pl/chopin2010). This website offers information in several languages: English, Japanese, Russian, French, Chinese, German and Spanish. Moreover, a small icon of 'photo code' (QR), when downloaded to a mobile phone or tablet gives users the possibility of free access to series of features: $\mathrm{mp} 3$ guide, photos, pieces of Chopin music. The idea of the 'Chopin Tourist Route' in Warsaw was created to commemorate 'the Chopin's Year 2010' in a form of 'educational walking path.' It was designed by the young artists from Design Association Group (in Polish: Towarzystwo Projektowe). Measured by its popularity this project 
has been successful. For example, it resulted in a reconfiguration of popular tourists 'beaten tracks' in Warsaw and offered the locals and visitors new sites to explore (among others, a narrow but charming Kozia Street). Made of polished black marble the elegant 'music benches' were located at 15 sites (Plac Krasińskich Square, Plac Zamkowy Square, Miodowa Street, Kozia Street, Krakowskie Przedmieście Street, Plac Saski Square, 'Royal Route', Tamka Street, Łazienki Royal Park) (Table 1).

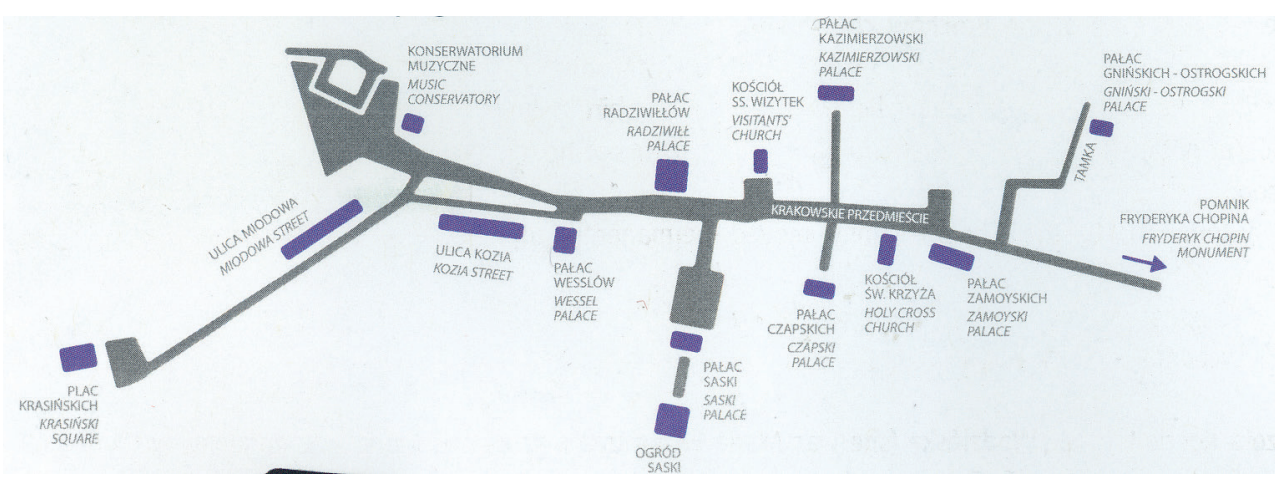

Fig. 1. Chopin Tourist Route in Warsaw. The location of the multimedia Chopin bench in Warsaw Source: Promotion Office of the City Council Warsaw, 2017

A mobile application "Chopin in Warsaw" was another useful tool providing an audioguide to locations related to Fryderyk Chopin. The augmented reality technology enables all users to look at the 19th century Warsaw, follow the events and listen to Chopin's music. It is also possible to take a photo (selfie) with Chopin. This mobile application, which became a significant tourist attraction, was the Warsaw Tourist Office initiative.

Our field survey, conducted in 2012-2014, revealed the opinions and attitudes of Warsaw residents towards the 'the Chopin Year 2010' in Warsaw and its impact on domestic and international tourism, showing that:

- $\quad 70 \%$ of the participants declared, that the anniversary events would help to associate Warsaw as being a 'cultural city' (perception of residents as well as domestic and international tourists)

- $74 \%$ of participants considered, that 'the Chopin Year 2010' in Warsaw enhanced the quality of life and the aesthetic of urban environment (especially the area of Krakowskie Przedmieście, Old Town and the 'Royal Route')

- $\quad 71 \%$ of participants were sure that the 'the Chopin Year 2010' increased the influx of tourist to Warsaw (also to Mazovia: Sochaczew, Brochów, Żelazowa Wola - places strongly connected with the Fryderyk Chopin myth).

Moreover, it was strongly underlined in the questionnaires, that in the past the cultural events in Warsaw were not regarded as part of the domestic tourism industry. Both the International Fryderyk Chopin Festival in 2010 and the 16th International Chopin Piano Competition were different. They aimed not only to be exclusive, international events. This time 
they were supposed to be available to all: the local community and tourists visiting Warsaw for other than these cultural events reason. They were organised to attract both music lovers but also people without special musical experiences. These important 'Chopin Year 2010' celebrations were aimed broader rather than to satisfy a narrow niche of professional musicians. Quite the opposite, they were intended to be widely popular, to draw the attention of numerous school groups from different villages and towns in Poland and also to meet the needs of the residents. Although until recently Chopin festivals were mostly shaped for international guests, on that year also common tourists and local community members were able to participate in many events, which were opened to everybody as free of charge 'street music' projects.

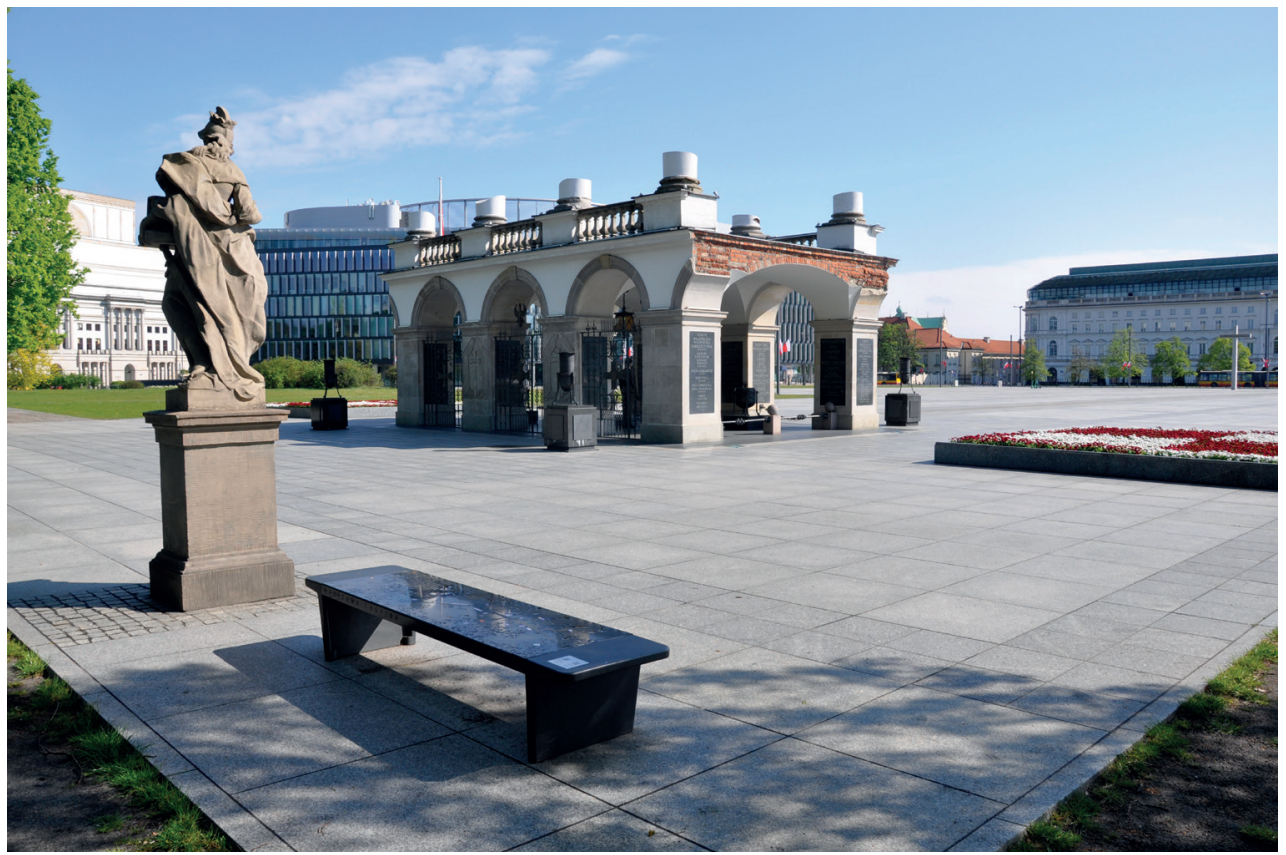

Fig. 2. The multimedia Chopin bench at the Pilsudski Place near the Tomb of Unknown Soldier, by the ruins of The Saxon Palace

Photos 2-12 and 14-15 were taken by Alicja, Jan, Anna Ostrowska-Tryzno. The photos were taken on May 2, 2020. It was on the Flag Day, before noon and during the quarantine announced due to the coronavirus epidemic. The photos of the empty city are very impressive and already provide an excellent testimony of the time of the plague (especially comparing photographs 12 and 13)

Among various positive effects mentioned by participants of our poll (tourists and the local community members), at least a few are worth to be mentioned:

1. First is the unquestionable and taken for granted - the 'old' city's asset. Chopin's festivals have been thought to bring prestige to the city and region, raise their profile on the outside and increase their rank around the world. As Warsaw is interested in attracting investors, the municipality should attract attention by developing a high profile in arts. 
2. Furthermore, the quality of life factors is strongly related to this. They are believed to be significant when various investment location decisions are made. Art events, especially regarded as 'high art', are always a good starting point for a successful place promotion.

3. The development of urban cultural tourism (arts tourism) in Warsaw has become a kind of mass phenomenon. 'High art' cultural tourism was in the past considered to be a rare form of spending free time; 2010 ('Chopin Festival 2010') proved it to be a rapidly growing form of tourism (in domestic and international aspects)

4. Perhaps, the most important advantage for Warsaw community was not only that 2010 was filled with many events connected with Fryderyk Chopin, but that for the first time, these events were easily accessible to the locals. Warsaw City Council deliberately designed the Chopin Festival to be 'open' to the Warsaw citizens, while still keeping the instance interesting to 'regular' visitors (professional musicians) from other parts of Poland and abroad.

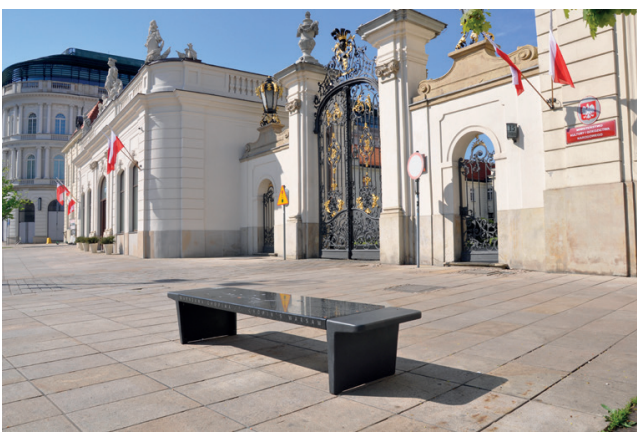

Fig. 3. The multimedia Chopin bench in front of the Potocki Palace

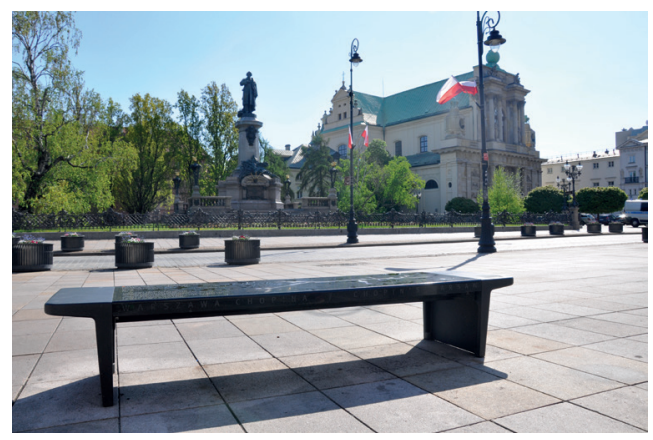

Fig. 5. The multimedia Chopin bench, by the Wessel Palace, with the view of the statue of Adam Mickiewicz

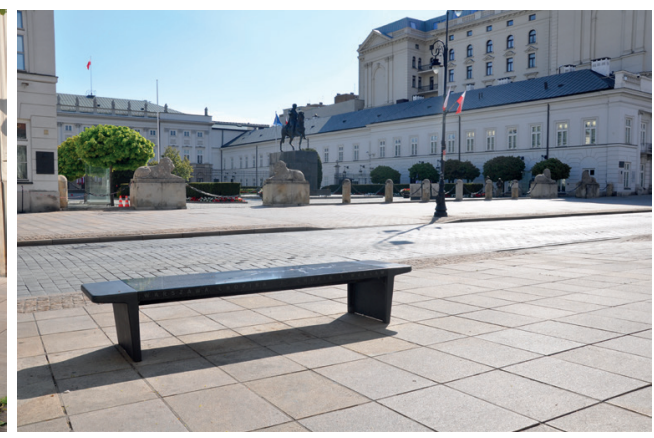

Fig. 4. The multimedia Chopin bench at the Presidential Palace (former Radziwill Palace)

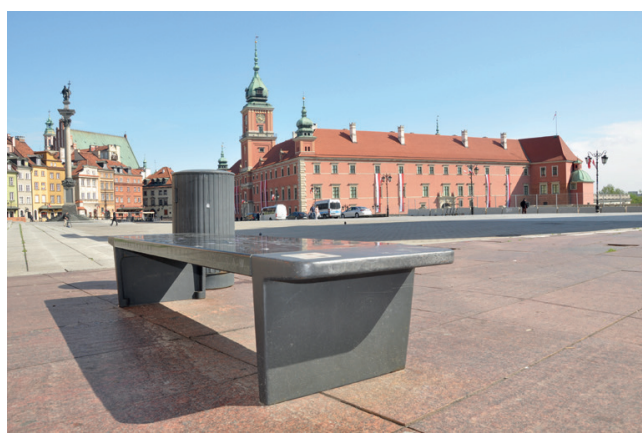

Fig. 6. The multimedia Chopin bench at the Castle Square

To sum up, cultural activities (in the form of art festivals) are widely perceived to have tourism potential. Moreover, if an event is unique and of high quality (as prestigious as Cho- 
pin's Festivals), then the possible visitors are even ready to travel for significant distance to attend it. It means there is a chance for meaningful development of art tourism. It should be considered as a very important and a highly beneficial tendency for society. 'Culturally inspired' tourists constitute a significant part not only in economic terms but also in a much broader context of possible advantages (promotion of the city and region, education and culture).

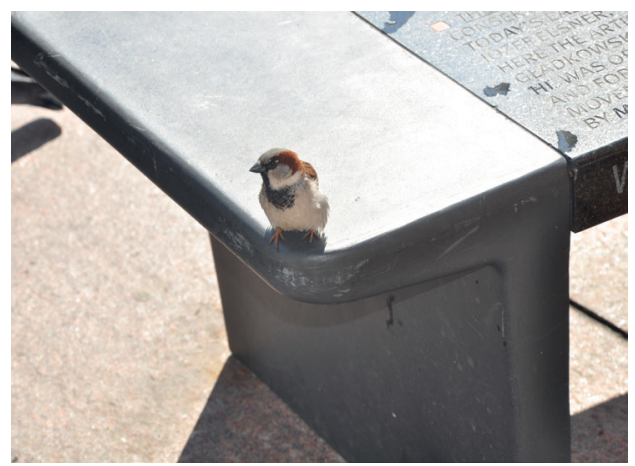

Fig. 7. A sparrow on the multimedia Chopin bench at the Castle Square

\section{Main Results and Conclusions}

Warsaw has always been an important destination for 'cultural tourism' due to its architectural relics (like the Old Town or the Royal Castle). It seems that today it is much more popular to travel to cities to experience live performances (drama, concerts, opera, ballet), which are not available locally. To understand the role of art festivals (like 'the Chopin Year $2010^{\prime}$ in Warsaw) it is necessary to consider this phenomenon in the context of changing approaches and trends arising nowadays in the Polish society. Moreover, changing the traditional organisation of these events by making them more inclusive and accessible (namely, the 'multimedia benches' located along the streets or free of charge concerts held in open public spaces, the Simphonia Varsovia orchestra projects: Praga District Chopin Concerts) helped to increase the popularity of the 'high art' among both tourists and the local community. Additionally, it seems that this wider impact of 'high art' might also become important in terms of economy (for tourist industry: revenue, jobs), urban regeneration ('Praga District Chopin Concerts' have already proved this theory) and marketing (attracting investments), improving the everyday life of the local community.

Essentially, Warsaw 'cultural product' developed for various mega-events like EURO 2012, World Youth Festival 2016 and others could not be based exclusively on the 'high culture' (theatre performances, opera and ballet performances, classical music festivals, museums, art galleries). They should also be inspired by the 'popular culture' - local music, regional gastronomy, local craft and meaningful multiculturalism (for example Jewish culture and traditions). Although all these can be labelled as 'tourism products, in our opinion the 'high culture' element is a very special factor in the city image. It is strongly connected with a specific site, local heritage or tradition. It is well-known and described in the academic literature tendency that as popular culture tends to be more globalised it becomes more diffused. The presence of 'high culture' helps to create a very special character of a tourist location [Ivanovic 2009; McKercher, Du Cros 2002; OECD 2009; Pawlikowska-Piechotka 2009, 2012; Selby 2004; Sigala 2006]. However, it should be underlined that all 'culture categories' are crucial 
for sustainable tourism development. They constitute integral components of the Warsaw lifestyle and are a part of everyday life.

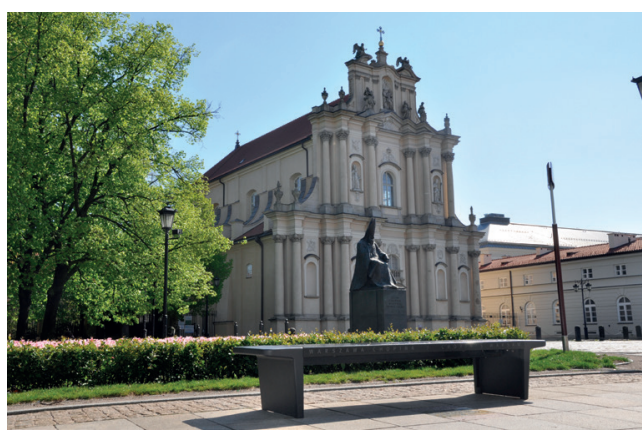

Fig. 8. The multimedia Chopin bench in front of the Church of St. Joseph of the Visitationists and the statue of Cardinal Stefan Wyszyński

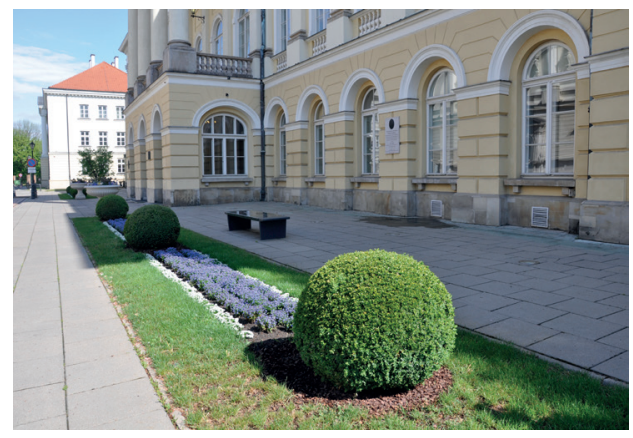

Fig. 9. The multimedia Chopin bench in front of the Kazimierzowski Palace at the Warsaw University Campus

Another question about the uneasy relationship between the 'high art', mass consumer taste and commercial interests might arise. There will always be a threat of popular culture somehow absorbing 'high art' and changing it (e.g. the high-quality music of Chopin festivals) into mass production. Moreover, such a tendency could be developed and tolerated with the best intentions (being seen as an excellent chance for local community development and urban regeneration). What's even more terrifying is that the mass culture might destroy a Chopin myth, when it is used as a cynical tool for commerce. The extent to which this compromises and harms artistic integrity of Chopin's masterpieces is, as we are afraid, rather debatable. Realistically speaking, we have to admit that it is difficult to conclude how far the 'high art' could be defined by its market value, rather than by its aesthetic appeal. Considering the number of tourists visiting Warsaw in 2010 (which was not very different from 2009) it did not seem to be the issue. Quite the opposite: the economic outcome of 'the Chopin Year 2010' might still be disputable [McKercher, Du Cros 2002; Page, Hall 2003; Panasiuk 2013; Rhodri 2009; Richards 2007].

Although Warsaw improved its hospitality and succeeded in creating a strong image of the 'high art' friendly place, perhaps it missed some commercial chances at the same time. In our opinion, this latter aspect is somewhat important and that the organisers of the future 'high art culture events' in Warsaw (especially Warsaw City Council, the Fryderyk Chopin Institute) need to consider it very carefully. What is especially worth noting is that 'culturally motivated' tourists, tend to be better educated and in a better financial situation than regular tourists. Although they constitute about half of the tourism market [UNWTO 2020], the 'culturally inspired tourists' are regarded as a very important segment. It doesn't refer to the tourism industry only, but to them being future ambassadors of the valuable Warsaw image. The question of achieving the desired balance between commercial effects and 'high art' projects quality still requires satisfying answers and optimal solutions to be identified. 
Although the economic impact, that the Chopin Festivals in Warsaw can have, might be questioned, the fact that a significant percentage of the local community and visitors attended these 'high art' performances is meaningful. In 2010, as many as 350000 spectators attended them (about 35\% of the Warsaw population) [by Alicja, Jan and Anna Ostrowska-Tryzno 2011]. These proportions might be even higher once the level of income and education provides Warsaw residents and visitors with adequate 'cultural capital'. It would allow them to appreciate classical music more easily. Moreover, it seems that Chopin festivals could be perceived as 'cultural resources' and could create a solid base for further tourism development in Warsaw.

It must be additionally underlined that most attempts of giving 'the Chopin Year 2010' celebrations a more popular character failed (for example, highly criticized cartoons and tacky souvenirs). It means that the values of 'high culture', especially Chopin myth, are recognized as national assets and must not be diminished.

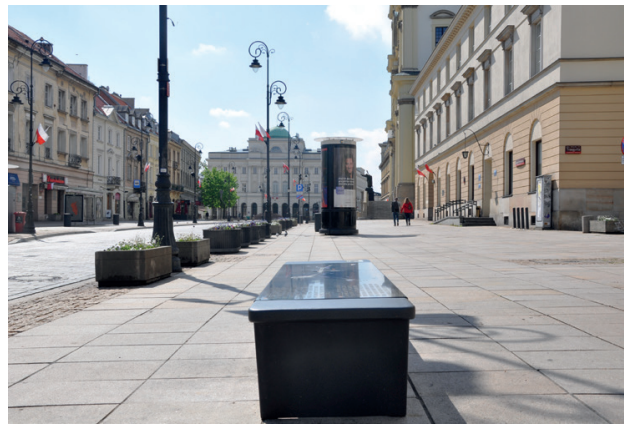

Fig. 10. The multimedia Chopin bench with the view of the Staszic Palace, located by the Czapski Palace

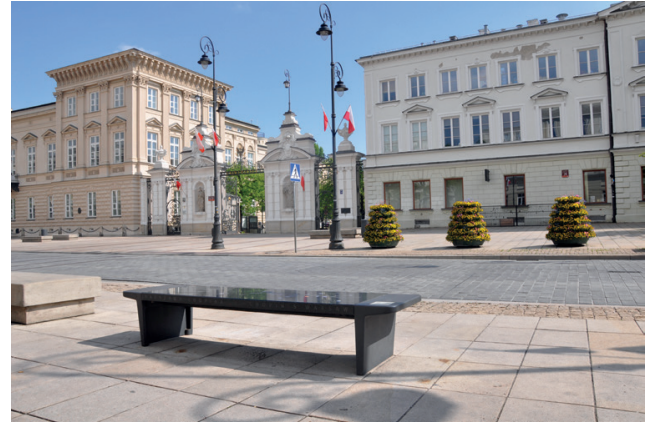

Fig. 11. The multimedia Chopin bench with the view of the Warsaw University Campus main entrance

All in all, 'the Chopin Year 2010' in Warsaw showed how important the cultural initiatives undertaken at the municipal and national level are. It portrayed their role in the revitalisation of urban culture, improvement of everyday urban life and in strengthening the self-esteem of the residents. For the Warsaw community, perhaps, it was the most important that 2010 was filled with many events connected with Fryderyk Chopin. For the first time, they were easily accessible to the locals (e.g. the 'Chopin Multimedia Benches') (Table 1). It was a great achievement of the City Council. It meant that a strategic decision was made to design 'the Chopin Year 2010' for Warsaw citizens, while still keeping the events open for tourists. It allowed the local community members, visitors from other parts of Poland and foreign guests to learn more about Polish culture, Warsaw, the traditions and history - especially about Chopin's connections with the city. Even though 'the Chopin Year 2010' in Warsaw did not appear to attract a greater number of tourists into the city, the locals enjoyed the events, that were being staged in many 'open-air' sites. These were, among others, the newly built 'Chopin Tourist Route' or concerts organised at public green spaces, like the popular summer 'Chopin Concerts under the Willow Tree' with a tradition lasting already for 90 years. This observation 
reflects the changes of local governance over recent decades as they rest more on the pluralist conception of the policymaking process.

When considering the future strategy of marketing for Warsaw and Mazovia Region as cultural tourism destinations it is necessary to evaluate various issues. Warsaw and Mazovia Region are diversified and their wealth has significant implications on tourist perception. It seems that special attention should be paid to attracting especially high-value visitors (cultu-

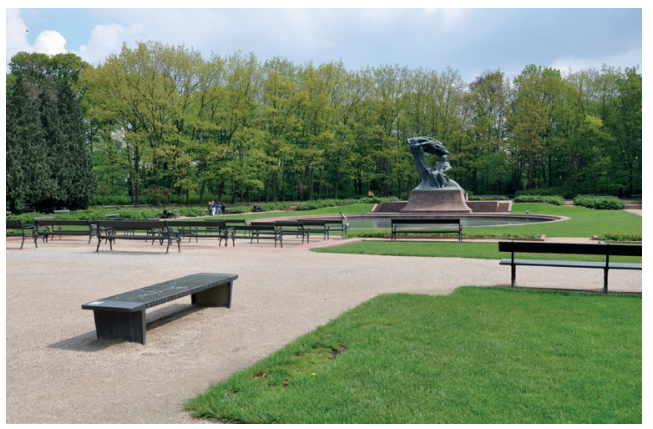

Fig. 12. The multimedia bench with the Fryderyk Chopin Monument in the Łazienki Royal Park

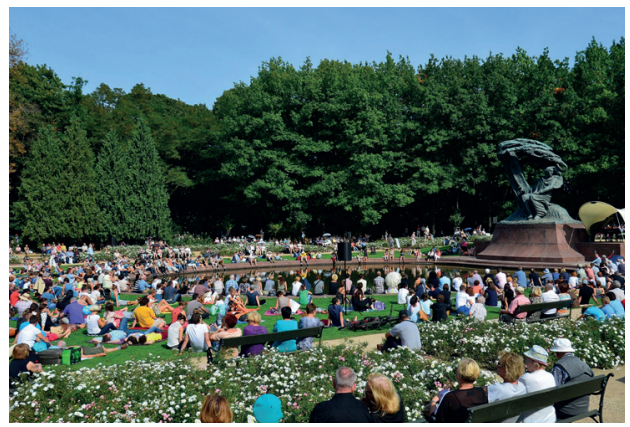

Fig. 13. Concert at the monument of Fryderyk Chopin in Warsaw - 'Concert under the Willow'

Phot. A. Grycuk, 2014 (Creative Commons Attribution Share Alike 3.0 Poland license, public domain)

rally motivated tourists) by increasing brand awareness of the cultural offer of Warsaw and Mazovia Region, encouraging year-round visits, increasing length of stay and generating partner investments [McKercher, du Cros 2002]. It is worth an effort as this form of tourism provides an opportunity for authentic cultural exchange between locals and visitors. It encourages local communities to learn more about their traditions, history and culture, boosts economic growth and helps to promote a region. The extent to which the culture could contribute to local development is the responsibility of the local government. It can ensure the quality of the events and support incentives that will induce both creativity and accountability, consider projects which would contribute to the sustainability of tourism: interactions and sharing [OECD 2018]. Considering these strong assets, it is possible to use cultural tourism as an opportunity to promote more innovative and more sustainable forms of tourism in Warsaw and Mazovia Region - also as a rescue plan after the pandemic COVID-19 crisis. It might bring benefits to public and private investors and the local communities.

Cultural tourism is one of the largest and fastest-growing tourism segments, generating on average about $40 \%$ of all European tourism (and 37\% worldwide) [UNWTO 2020]. Today we face the catastrophic impact of the pandemic, caused by virus Covid-19, on the tourism industry. This puts approximately 13 million European jobs at risk. 


\section{Does cultural tourism have any future in the post-pandemic world?}

In May 2020 European Cultural Tourism Network (ECTN) announced a manifesto 'Cultural Heritage: a powerful catalyst for the future of Europe', released on the occasion of Europe Day (this year marking the 70th anniversary of the Shuman Declaration of European Integration). The ECTN declaration states clearly that 'Cultural tourism will be the main driver for the recovery of the European tourism sector.' and consequently 'A specific and targeted campaign and support is needed by EU institutions and EU member states towards investments in sustainable cultural tourism development and promotion.' [ECTN 2020].

Unquestionably, 'the Chopin Year 2010' project in Warsaw proved it was ideally set in Warsaw, based on the authentic spirit of the city, enthusiastic support of the local community and close connections with the great master composer. Although a whole decade has passed, 'Music Route' with the 'music benches' still seems to be a significant attraction for cultural tourists and the local community. By considering our survey results and 'culture consumers' opinions it becomes apparent that some 'high art' events of great prestige, such as 'the Chopin Year 2010', are beneficial equally to the residents and to domestic and international visitors. As it seems, this might also be a rescue plan implemented after the COVID-19 pandemic, launched together with the main assets of Warsaw and Mazovia Region - the intangible and tangible heritage.

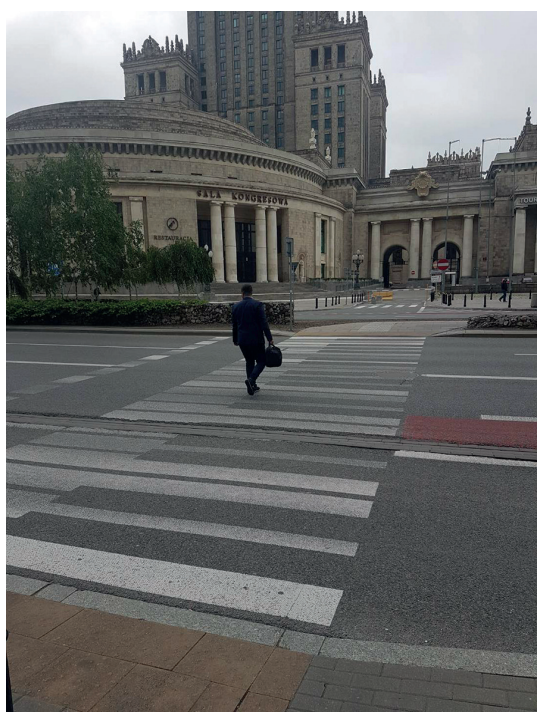

Fig. 14. Pedestrian crossing in the form of a piano keybord (Chopin Year 2010) in Emilii Plater Street in Warsaw

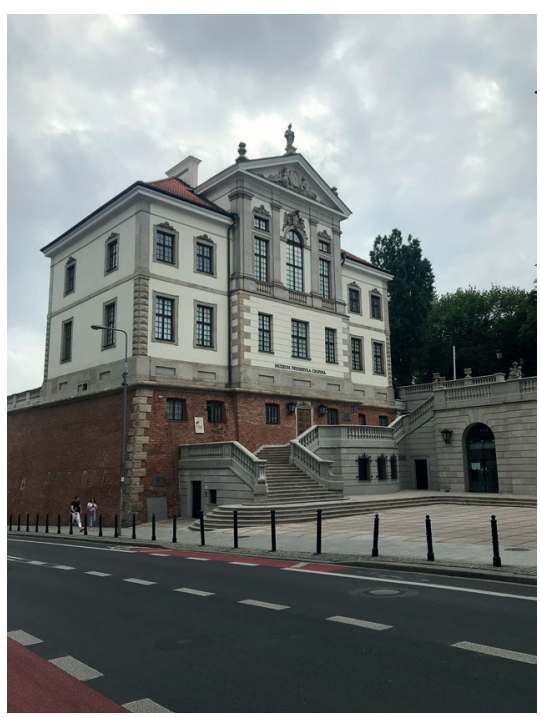

Fig. 15. Ostrogski Palace, Chopin Museum in Warsaw 


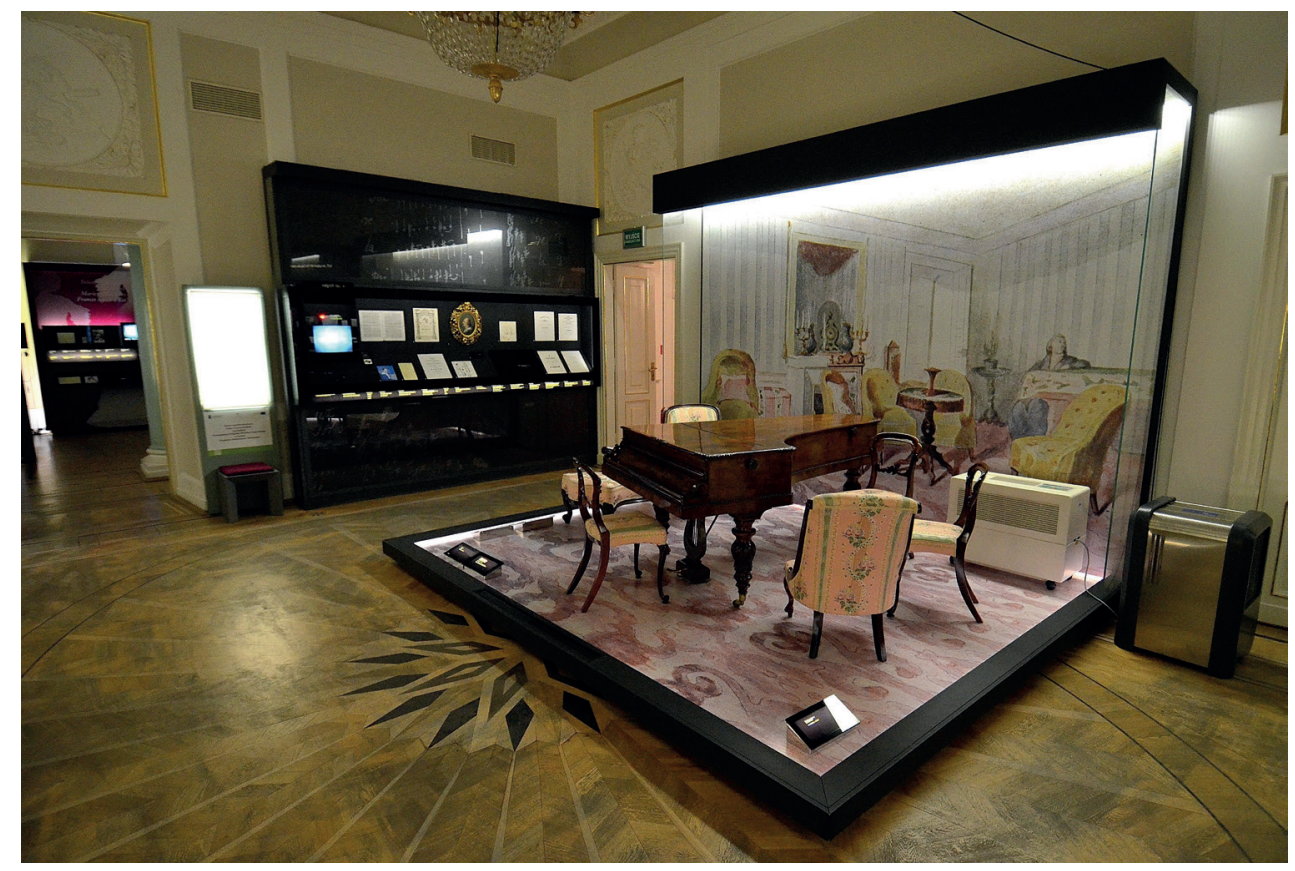

Fig. 16. Fryderyk Chopin Museum in Warsaw. Composer's last piano made by the Playel Company (no 14810). Chopin played and composed on this instrument in 1848-49

Phot. A. Grycuk

Acknowledgements

This paper is based on the research project carried out by the authors at the Faculty of Tourism and Recreation, the Joseph Pilsudski University of Physical Education in Warsaw in 2011-2017. The research project was supported by the Ministry of Science and Higher Education (grant: DS-144). 
Table 1. 'Chopin Tourist Route' and location of the multimedia benches in Warsaw: spatial, historic and music context of this educational walking path

\begin{tabular}{|c|c|c|c|}
\hline No. & Location & $\begin{array}{l}\text { Spatial and historic context of the multimedia } \\
\text { benches }\end{array}$ & Music context \\
\hline 1. & $\begin{array}{l}\text { Krasiński Square } \\
\text { in Warsaw }\end{array}$ & $\begin{array}{l}\text { This Square used to house the National Theatre } \\
\text { building, where in March } 1830 \text { Fryderyk Chopin } \\
\text { presented his famous Concerto in F minor. This } \\
\text { was also where in October } 1830 \text { he played his last } \\
\text { farewell concert before leaving the country }\end{array}$ & $\begin{array}{r}\text { Mazurka in } \\
\text { A minor, Op. } 17 \\
\text { No. } 4 ; 39\end{array}$ \\
\hline 2. & $\begin{array}{l}\text { Miodowa Street } \\
\text { in Warsaw }\end{array}$ & $\begin{array}{l}\text { In Chopin's days in Warsaw, the entire social life } \\
\text { of the capital used to be concentrated here. The } \\
\text { popular local cafes, such as 'Pod Kopciuszkiem', } \\
\text { 'Dziurka' and 'Honoratka' - for centuries have } \\
\text { been the venues of meetings for artists and young } \\
\text { people - were visited by Chopin almost daily }\end{array}$ & $\begin{array}{r}\text { Mazurka in } \\
\text { A minor, } \\
\text { Op. } 68 ; 34\end{array}$ \\
\hline 3. & $\begin{array}{l}\text { Kozia Street in } \\
\text { Warsaw }\end{array}$ & $\begin{array}{l}\text { This narrow, charming street, used to be an } \\
\text { important transport route in Chopin's times. The } \\
\text { 'U Brzezińskiej' cafe was his favourite place to visit }\end{array}$ & Hulanka' song; 29 \\
\hline 4. & $\begin{array}{l}\text { The Music } \\
\text { University in } \\
\text { Warsaw }\end{array}$ & $\begin{array}{l}\text { The place which now features a square used to } \\
\text { house the Music Conservatory where Fryderyk } \\
\text { Chopin studied musical composition when living } \\
\text { in Warsaw }\end{array}$ & $\begin{array}{r}\text { Waltz in E-flat } \\
\text { major, } \\
\text { Op. } 18 ; 39\end{array}$ \\
\hline 5. & $\begin{array}{l}\text { Wessel Palace in } \\
\text { Warsaw }\end{array}$ & $\begin{array}{l}\text { This was where on November 2nd } 1830 \text { Fryderyk } \\
\text { Chopin got on a stagecoach and started his great } \\
\text { European trip: first to Vienna and further to Paris }\end{array}$ & $\begin{array}{r}\text { Grand Polonaise } \\
\text { in E-flat major, } \\
\text { Op. 22; } 35\end{array}$ \\
\hline 6. & $\begin{array}{l}\text { Radziwiłł Palace } \\
\text { in Warsaw }\end{array}$ & $\begin{array}{l}\text { This was where on February 24th } 1818 \text { Fryderyk } \\
\text { Chopin, aged only eight, gave his first public } \\
\text { performance }\end{array}$ & $\begin{array}{r}\text { Rondo in C } \\
\text { minor, Op.1; } 32\end{array}$ \\
\hline 7. & $\begin{array}{l}\text { Saski Palace in } \\
\text { Warsaw }\end{array}$ & $\begin{array}{l}\text { The Chopin family moved there in } 1810 \text { after } \\
\text { Fryderyk Chopin's father had accepted a job at the } \\
\text { famous Warsaw Lyceum, which was located there }\end{array}$ & $\begin{array}{r}\text { Mazurka in B } \\
\text { major, } \\
\text { Op. } 7 \text { No. } 1 ; 36\end{array}$ \\
\hline 8. & $\begin{array}{l}\text { Saski Garden in } \\
\text { Warsaw }\end{array}$ & $\begin{array}{l}\text { This oldest public park in Warsaw was where the } \\
\text { young Fryderyk Chopin spent happy recreation hours } \\
\text { while he and his family resided at the Saski Palace }\end{array}$ & $\begin{array}{r}\text { Nocturne in } \mathrm{H} \\
\text { major, } \\
\text { Op. } 9 \text { No. } 3 ; 47\end{array}$ \\
\hline 9. & $\begin{array}{l}\text { The Visitants' } \\
\text { Church in } \\
\text { Warsaw }\end{array}$ & $\begin{array}{l}\text { In Fryderyk Chopin's time, the Sunday masses } \\
\text { for students of the Warsaw Lyceum traditionally } \\
\text { took place there, during which Fryderyk Chopin, } \\
\text { aged only 15, used to play the organ, performing } \\
\text { the function of the Lyceum organist }\end{array}$ & $\begin{array}{r}\text { Largo in E-flat } \\
\text { major } \\
\text { (Op. posth.); } 46\end{array}$ \\
\hline
\end{tabular}




\begin{tabular}{|c|c|c|c|}
\hline No. & Location & $\begin{array}{l}\text { Spatial and historic context of the multimedia } \\
\text { benches }\end{array}$ & Music context \\
\hline 10. & $\begin{array}{l}\text { Kazimierzowski } \\
\text { Palace in } \\
\text { Warsaw }\end{array}$ & $\begin{array}{l}\text { In } 1817 \text { the Warsaw Lyceum and the newly } \\
\text { established Warsaw University were located } \\
\text { there. The Fryderyk Chopin family came to reside } \\
\text { in the right-wing annexe }\end{array}$ & $\begin{array}{r}\text { Waltz in E } \\
\text { minor } \\
\text { (Op. posth.); } 45\end{array}$ \\
\hline 11. & $\begin{array}{l}\text { Czapski Palace } \\
\text { in Warsaw }\end{array}$ & $\begin{array}{l}\text { The Chopin family moved there in } 1827 \text { and } \\
\text { Fryderyk Chopin got a room equipped with } \\
\text { a piano. The former residence of the Chopin } \\
\text { family, located on the second floor, now features } \\
\text { the Chopin Parlour - the Fryderyk Chopin } \\
\text { Museum in Warsaw annexe, displaying some } \\
\text { memorabilia of the great composer }\end{array}$ & $\begin{array}{r}\text { Waltz in D-flat } \\
\text { major, } \\
\text { Op. } 64 \text { No } 1 ; 42\end{array}$ \\
\hline 12. & $\begin{array}{l}\text { Holy Cross } \\
\text { Church in } \\
\text { Warsaw }\end{array}$ & The place where Chopin's heart rests & $\begin{array}{r}\text { Sonata in B } \\
\text { minor, Op. } 35 ; 45\end{array}$ \\
\hline 13. & $\begin{array}{l}\text { Zamoyski Palace } \\
\text { in Warsaw }\end{array}$ & $\begin{array}{l}\text { Chopin's sister, who gathered the heritage of her } \\
\text { brother, used to live here. In } 1863 \text { an attempt on } \\
\text { the life of a Tsar's governor was made through the } \\
\text { palace windows, in retaliation for which all the } \\
\text { tenants were removed from their flats and their } \\
\text { entire property was destroyed. Among the objects } \\
\text { thrown through the windows and burned was the } \\
\text { original Fryderyk Chopin's piano }\end{array}$ & $\begin{array}{r}\text { Etude in C } \\
\text { minor, Op. } 10 \\
\text { No. } 12 ; 42\end{array}$ \\
\hline 14. & $\begin{array}{l}\text { Gniński- } \\
\text { Ostrogski Palace } \\
\text { in Warsaw }\end{array}$ & $\begin{array}{l}\text { The location of the Fryderyk Chopin Museum, } \\
\text { next to which the National Fryderyk Chopin } \\
\text { Institute is located }\end{array}$ & $\begin{array}{r}\text { Ballad in } \mathrm{F} \\
\text { minor, } \\
\text { Op. } 52 ; 42\end{array}$ \\
\hline 15. & $\begin{array}{l}\text { The Fryderyk } \\
\text { Chopin } \\
\text { Monument in } \\
\text { Warsaw }\end{array}$ & $\begin{array}{l}\text { This most famous monument of the composer } \\
\text { in the world, the masterpiece of Polish sculptor } \\
\text { - Wacław Szymanowski (1926), located in the } \\
\text { southern part of Royal Łazienki Park, opposite the } \\
\text { gate in Aleje Ujazdowskie, near Belvedere, venue } \\
\text { of summer open-air Chopin Concerts under the } \\
\text { Willow Tree }\end{array}$ & $\begin{array}{r}\text { Polonaise in } \\
\text { A major, Op. } 40 \\
\text { No. } 1 ; 39\end{array}$ \\
\hline
\end{tabular}

Source: based on the research project carried out by the authors at the Faculty of Tourism and Recreation, the Joseph Pilsudski University of Physical Education in Warsaw in the 2011-2017 years and supported by Ministry of Science and Higher Education (grant: DS-144), Promotion Office of Warsaw City Council and the National Fryderyk Chopin Institute (2011-2017) 


\section{References}

Archer B., Cooper Ch., Ruhanen L., 2004, The Positive and Negative Impacts of Tourism [in:] W. F. Theobald (ed.), Global Tourism, Elsevier Oxford, pp. 75-103.

Statistic Yearbook 2010, 2011, Central Statistic Office in Warsaw, Warsaw [in Polish, in English]. Dallen J.T., Boyd S. W., 2003, Heritage Tourism, Prentice-Hall, Harlow.

Finn M., Elliott-White M., 2000, Tourism E Leisure Research Methods, Pearson-Longman, Harlow. Fryderyk Chopin Heritage Preservation Act, 2001, Journal of Laws 2001, No 16, Item 168; Act of 3rd February 2001 (in Polish).

Ivanovic M., 2009, Cultural Tourism, Juta and Company Ltd., Cape Town.

Kowalczyk A. (ed.), 2009, Turystyka kulturowa. Spojrzenie geograficzne, Wydział Geografii i Studiów Regionalnych UW, Warszawa.

Law Chr. M., 2002, Urban Tourism: The Visitor Economy and the Growth of Large Cities, Continuum, London.

Loykie L., Edmunds J., 2007, Key Concepts in Tourism, Palgrave, New York.

McKercher B., Du Cros H., 2002, Cultural Tourism. The partnership between tourism and cultural heritage management, Routledge, New York.

National Fryderyk Chopin Institute NFCHI, 2010, Chopin Express, a daily bulletin issued during the 16th International Fryderyk Chopin Piano Competition in Warsaw (SeptemberOctober 2010), National Fryderyk Chopin Institute, Warsaw.

National Fryderyk Chopin Institute NFCHI, 2011, Chopin 1810-2010, National Fryderyk Chopin Institute, Warsaw.

Organisation for Economic Co-Operation and Development, 2009, The Impact of Culture on Tourism, OECD, Paris.

Organisation for Economic Co-Operation and Development, 2018, Culture and Local Development, OECD, Paris.

Page S. J., Hall M. C., 2003, Managing Urban Tourism, Prentice Hall, Harlow.

Phillimore J., Goodson L., 2004, Qualitative Research in Tourism, Routledge, New York.

Panasiuk A., 2013, Marketing w turystyce i rekreacji, Wydawnictwo Naukowe PWN, Warszawa.

Pawlikowska-Piechotka A., 2009, Zagospodarowanie turystyczne i rekreacyjne, Novae Res, Gdynia.

Pawlikowska-Piechotka A., 2012, Planowanie przestrzeni turystycznej, Novae Res, Gdynia.

Rhodri T., 2009, Managing Regional Tourism, Great Northen Books, York. 
Richards G., 2007, Cultural Tourism. Global and local perspectives, Routledge, New York.

Rohrscheidt A.M., 2008, Turystyka kulturowa: fenomen, potencjat, perspektywy, Wydawnictwo GWSHM, Gniezno.

Selby M., 2004, Understanding urban tourism: image, culture, experience, IB TAURIS, London.

Sigala M., David L., 2006, International Cultural Tourism, Elsevier, Oxford.

Smith M. K., 2003, Issues in cultural tourism studies, Routledge, London.

UN World Tourism Organisation, 2002, City Tourism and Culture - The European Experience, UN WTO, RGETC Madrid.

UN World Tourism Organisation, 2017, Declaration on Tourism and Culture, adapted during the 22nd Session of the General UN WTO Assembly, Chengdu, China.

\section{Web pages}

www.e-warsaw.pl [access in 2015, in Polish, in English]

www.um.warszawa.pl/chopin2010 [access in 2015, in Polish, in English]

www.culturaltourism-network-eu [access in 2020, in English]

www.unwto.org [access in 2020, in English]

www.oecd.org [access in 2020, in English]

\section{Dziedzictwo Fryderyka Chopina z perspektywy społeczności lokalnej i turystów}

\section{STRESZCZENIE}

Tradycje podróży są bez wątpienia motywacją dla doznań kulturowych, znaną od początków rozwoju turystyki, obecnie coraz częściej stanowiąca podstawowy cel. Zatem ważne wydaje się zbadanie, jakie walory kulturowe i jakie wydarzenia są silnymi magnesami dla wyboru danej destynacji. Innym zagadnieniem jest poszukiwanie odpowiedzi na pytania: czy są to atrakcje interesujące jednakowo dla turystów i dla społeczności lokalnej? W jakim stopniu mają udział w popularyzacji kultury, edukacji, promocji miejsca, kreowaniu jego pozytywnego wizerunku? Kolejną kwestią którą jak się wydaje warto rozważyć, jest udział nie tylko kultury popularnej (koncerty gwiazd muzyki popularnej), ale i znaczenie 'kultury wysokiej' (wystaw, festiwali muzyki klasycznej, wydarzeń artystycznych o ponadlokalnym znaczeniu) w motywacjach podejmowanych podróży. Celem naszych badań, podjętych w ramach projektu statutowego ds.-144 AWF, było poznanie wpływu Roku Jubileuszowego Fryderyka Chopina 2010 w Warszawie na rozwój turystyki kulturowej.

Słowa kluczowe: Fryderyk Chopin, wydarzenia kulturalne, społeczność lokalna, turyści, Warszawa 
I. Analyses and Studies / Analizy i Studia

$\overline{\text { Anna Ostrowska-Tryzno }-P h D ~ i n ~ p h y s i c a l ~ c u l t u r e, ~ w o r k s ~ a t ~ t h e ~ F a c u l t y ~ o f ~ P h y s i c a l ~ E d u c a t i o n ~ a t ~ t h e ~ J o ́ z e f ~ P i t s u d s k i ~ U n i v e r s i t y ~ o f ~}$ Physical Education in Warsaw. She specializes in sustainable urban development and responsible business tourism. She is currently focusing her research activity on issues related to outdoor sports and recreation infrastructure in cities, accessible for children and youth, the elderly and people with disabilities.

e-mail:anna.tryzno@awf.edu.pl

Anna Ostrowska-Tryzno - dr nauk o kulturze fizycznej, adiunkt na Wydziale Wychowania Fizycznego AWF w Warszawie. Specjalizuje się w problematyce zrównoważonego rozwoju miast oraz odpowiedzialnej turystyce biznesowej. Aktualnie koncentruje swojq aktywność badawczą na zagadnieniach dotyczących plenerowej infrastruktury sportowo-rekreacyjnej w miastach, dostępnej dla dzieci i młodzieży, osób starszych oraz osób z niepełnosprawnościami.

e-mail:anna.tryzno@awf.edu.pl

ORCID: 0000-0002-2539-7900

Anna Pawlikowska-Piechotka, professor, PhD Eng Arch - architect and urban planner, in 2004-2014 a visiting professor at University College Birmingham (United Kingdom), Charles University of Prague (Czech Republic), University of Lahti (Finland), University of Saragossa (Spain), University of Evora (Portugal), University of Viseau (Portugal), Holar University (Iceland). In her research, she focuses on the usage of cultural heritage for sustainable tourism and responsible planning for tourism, sport and recreation. She participated in several international research projects (Germany, Sweden, Holland, UK, Poland, Turkey); she is the author of over two hundred scientific publications, including several monographs, papers published in English, German, Polish and Serbian; co-author of several architectural and urban plans of recreation and tourist space (commissioned in Poland, Germany, Nigeria and Libya) and utility models of recreation facilities for disabled - formally registered in the Polish Patent Office.

Contact: the Józef Piłsudski University of Physical Education in Warsaw;

e-mail:anna.piechotka@gmail.com

Anna Pawlikowska-Piechotka, prof. dr hab. inż. arch. - architekt i urbanista, w latach 2004-2014 profesor wizytujący na University College Birmingham (Wielka Brytania), Charles University of Prague (Czechy), University of Lahti (Finlandia), University of Saragossa (Hiszpania), University of Evora (Portugalia), University of Viseau (Portugalia), Holar University (Islandia). W swoich badaniach koncentruje się na wykorzystaniu dziedzictwa kulturowego dla zrównoważonego rozwoju turystyki i odpowiedzialnego planowania przestrzeni turystyki, sportu i rekreacji. Uczestniczyła w kilku międzynarodowych projektach badawczych (Niemcy, Szwecja, Holandia, Wielka Brytania, Polska, Turcja); jest autorem ponad dwustu publikacji naukowych, w tym kilku monografii, tekstów opublikowanych w języku angielskim, niemieckim, polskim i serbskim; współautor kilkudziesięciu planów architektonicznych i urbanistycznych (zrealizowanych w Polsce, Niemczech, Nigerii i Libii) oraz wzorów użytkowych obiektów rekreacyjnych dla osób niepełnosprawnych - formalnie zarejestrowanych w Urzędzie Patentowym RP.

Kontakt: Akademia Wychowania Fizycznego Józefa Piłsudskiego w Warszawie;

e-mail:anna.piechotka@gmail.com

ORCID: 0000000304290327 